University of Nebraska - Lincoln

DigitalCommons@University of Nebraska - Lincoln

March 2005

\title{
COLLAGENUS DASYSTERNUS, A NEW GENUS AND SPECIES OF DYNASTINAE FROM EASTERN VENEZUELA WITH A KEY TO THE NEW WORLD GENERA OF PENTODONTINI (COLEOPTERA: SCARABAEIDAE: DYNASTINAE)
}

Brett C. Ratcliffe

University of Nebraska-Lincoln, bratcliffe1@unl.edu

Martin Hardy

Blainville, Quebec

Follow this and additional works at: https://digitalcommons.unl.edu/entomologypapers

Part of the Entomology Commons

Ratcliffe, Brett C. and Hardy, Martin, "COLLAGENUS DASYSTERNUS, A NEW GENUS AND SPECIES OF DYNASTINAE FROM EASTERN VENEZUELA WITH A KEY TO THE NEW WORLD GENERA OF PENTODONTINI (COLEOPTERA: SCARABAEIDAE: DYNASTINAE)" (2005). Papers in Entomology. 22. https://digitalcommons.unl.edu/entomologypapers/22

This Article is brought to you for free and open access by the Museum, University of Nebraska State at DigitalCommons@University of Nebraska - Lincoln. It has been accepted for inclusion in Papers in Entomology by an authorized administrator of DigitalCommons@University of Nebraska - Lincoln. 


\title{
Collagenus dasysternus, a New Genus and Species of Dynastinae from Eastern Venezuela with a Key to the New World Genera of Pentodontini (Coleoptera: Scarabaeidae: Dynastinae)
}

\author{
BRETT C. RATCLIFFE \\ Systematics Research Collections \\ W436 Nebraska Hall \\ University of Nebraska \\ Lincoln, NE 68588-0514, U.S.A. \\ bratcliffe1@unl.edu \\ AND \\ Martin HaRdy \\ 24 rue du Chemin du Roy \\ Blainville, QC J7C 4R4, CANADA
}

Whenever I hear of the capture of rare beetles, I feel like an old war horse at the sound of a trumpet - Charles Darwin

\begin{abstract}
Collagenus dasysternus Ratcliffe and Hardy, new genus and species, is described from eastern Venezuela. We include a revised key to the 26 genera of New World Pentodontini.
\end{abstract}

When the second author (Hardy) first saw this Venezuelan specimen in the Henry Howden collection, he could not readily place it to genus. When the first author (Ratcliffe) received the specimen from Hardy for examination in mid-2003, he was immediately taken with its gestalt similarity with the genus Coscinocephalus Prell that occurs in Arizona and Mexico. Unfortunately, there is only one specimen, but our examination revealed such unique character states that were indicative of a new, undescribed genus and species that we describe it here. We utilize the Phylogenetic Species Concept as outlined by Wheeler and Platnick (2000). This concept defines species as the smallest aggregation of sexual populations diagnosable by a unique combination of character states. Whether this species occurs rarely in nature remains unknown, but the area from which it was collected is readily accessible if someone wanted to make a concerted effort to find additional specimens. During a visit by one of us (Ratcliffe) to the extensive collections of the Universidad Central de Venezuela in Maracay in 1999, similar specimens were not found.

With the new genus described here, the tribe Pentodontini now contains 26 genera and a few more than a hundred species in the New World. Endrödi $(1969,1985)$ comprehensively reviewed and defined the Pentodontini, and this tribal concept was used by Ratcliffe (2002) in the latest generic treatment of the North American dynastines. Endrödi's definition did not address monophyly, and we remain concerned that the Pentodontini (as currently defined) may not be monophyletic. In particular, the head and pronotal armature as well as the form of the meso- and metatibiae used to characterize the tribe are not consistently expressed. 
Until such time as the monophyly of the Pentodontini is resolved, we place our new genus in the Pentodontini because it possesses the following characters: a weak tubercle on the frons, a strong frontoclypeal carina, tridentate foretibia, and a truncate metatibia with a fringe of short, spine-like setae on the apex.

The last generic keys to adults of the New World Pentodontini were by Ratcliffe (1981) and Endrödi (1985). Morón and Ratcliffe (1997) transferred the genus Coscinocephalus from the Cyclocephalini to the Pentodontini, but it has never been incorporated into a comprehensive generic key. In addition, the genus Oryctomorphus Guérin-Meneville has bounced back and forth between the Rutelinae (i.e., Machatschke 1972) and Dynastinae (i.e., Endrödi 1985). It is in the key by Ratcliffe (1981), but molecular data based on 28S and 18S DNA gene regions suggest that Oryctomorphus is a member of the subfamily Rutelinae (A. Smith and D. Hawks, unpubl. data), and so it is not included in the present key. We provide a revised key to the adults of all the New World genera of Pentodontini. Morón and Ratcliffe (1997) provided a key to nine genera of larval Pentodontini.

\section{Collagenus Ratcliffe and Hardy, new genus}

Type Species. Collagenus dasysternus Ratcliffe and Hardy, new species, here designated.

Description. Scarabaeidae, Dynastinae, Pentodontini. Form: Suboval, pronotum widest at middle, elytra widest past middle. Length of only known specimen $20.1 \mathrm{~mm}$. Color: Light and dark reddish brown. Head: Frons at center with weakly elevated, flattened boss. Frontoclypeal carina strong, elevated completely from side to side. Clypeus with apical rim swollen, strongly reflexed; venter of clypeus greatly swollen and plump. Mandibles small, subtriangular, completely hidden beneath clypeus. Mentum strongly swollen and protuberant ventrally. Pronotum: Surface completely, moderately punctate. Elytra: Surface with 5 distinctly furrowed striae $(2$ double rows plus 1 sutural stria). Pygidium: Surface completely, moderately punctate, strongly convex. Legs: Legs with moderately dense, long, yellowish brown setae. Foretibia tridentate; apical tooth slightly removed, larger, curved; apex obliquely truncate. Apices of meso- and metatibiae each with fringe of stout bristles. Tarsi and claws slender. Venter: Thoracic sternites with dense, long, yellowish brown setae. Prosternal process a small, rounded protuberance. Abdominal sternites shiny, glabrous.

Diagnosis. Collagenus can be easily distinguished from similar genera because of the unique form of the greatly thickened rim on the broadly parabolic clypeal apex, ventrally protuberant mentum, strong frontoclypeal carina, absence of tubercles or a fovea on the pronotum, long tarsi, densely setose thoracic sternites, small rounded prosternal process, and the crenulate apex of the posterior tibiae.

Etymology. One of the most striking features of this new genus is the greatly swollen apical rim and venter of the clypeus that gives the impression of swollen "lips." In some circles today, it is cosmetically fashionable to enlarge human lips by injecting them with collagen, an insoluble fibrous protein. Collagen is derived from the Greek kolla, meaning glue. Collagenus is a play on combining "collagen" (in reference to its use to enlarge lips) and "genus" (in reference to this new genus), hence (loosely) the big-lipped genus. The name Collagenus is considered masculine.

\section{Collagenus dasysternus Ratcliffe and Hardy, new species}

(Figs. 1-4)

Type Material. Holotype labeled "Ven: Bolivar, $10 \mathrm{~km} \mathrm{~N}$ Corocito, 18.VI-3. VII.87, S\&J Peck, FIT, R. Caura rainforest." Holotype deposited at the Canadian Museum of Nature (Ottawa, Canada). 


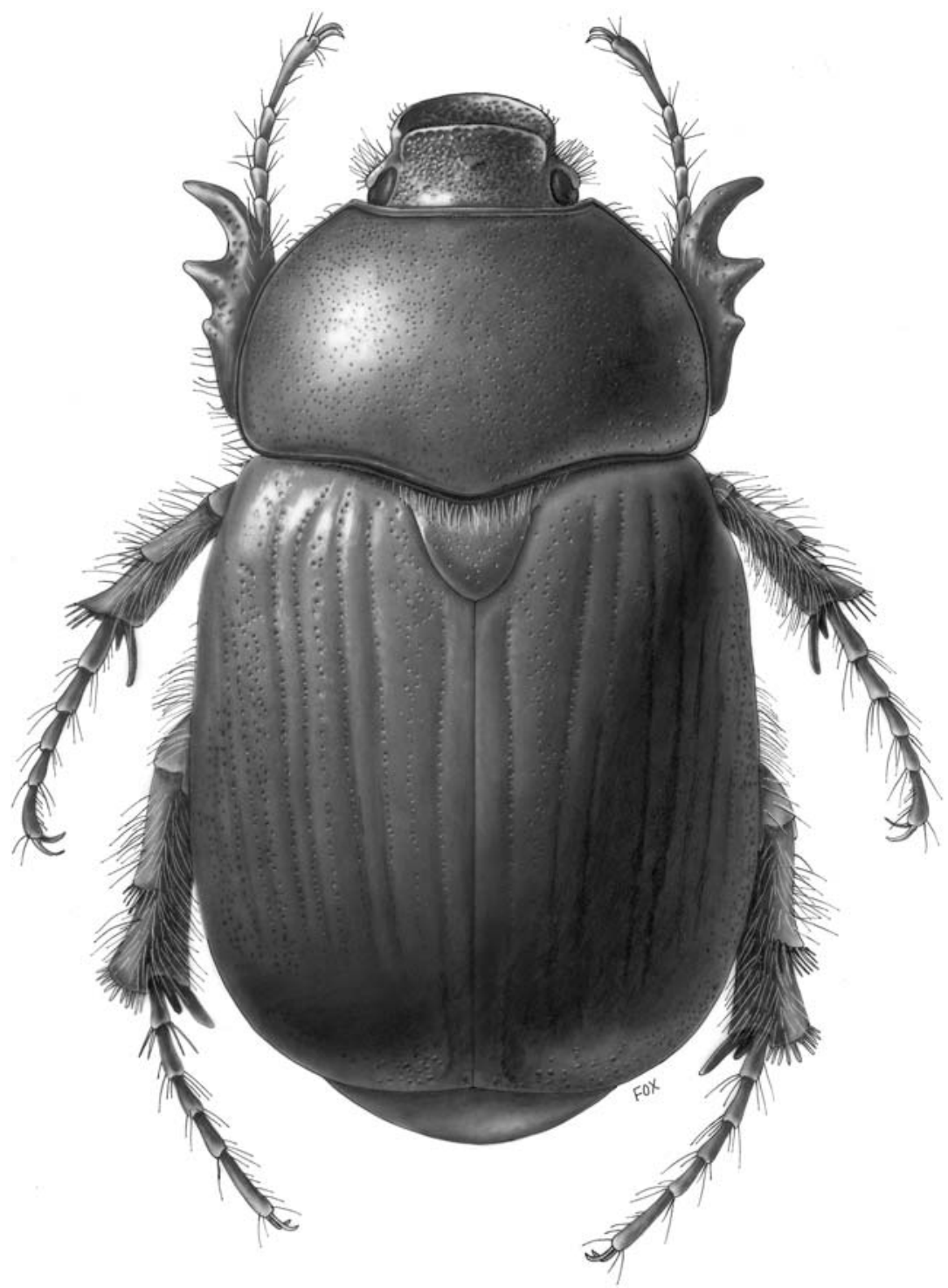

Fig. 1. Habitus of Collagenus dasysternus Ratcliffe and Hardy, new genus and species.

Description of Holotype. Male (Fig. 1). Length from apex of clypeus to apex of elytra 20.1 $\mathrm{mm}$; width at humerus $9.6 \mathrm{~mm}$. Color of dorsum and legs dark reddish brown, color of pygidium and venter reddish brown. Head: Frons with surface densely, coarsely rugopunctate; center with small, transverse, feebly elevated boss. Frontoclypeal carina strong, elevated, complete from side to side, weakly arcuate towards posterior. Clypeus with surface densely, coarsely rugopunctate; apex broadly parabolic, with strongly thickened anterior rim, rim strongly reflexed (Fig. 2); clypeus greatly swollen ventrally. Mandibles small, subtriangular, slender, completely hidden beneath 


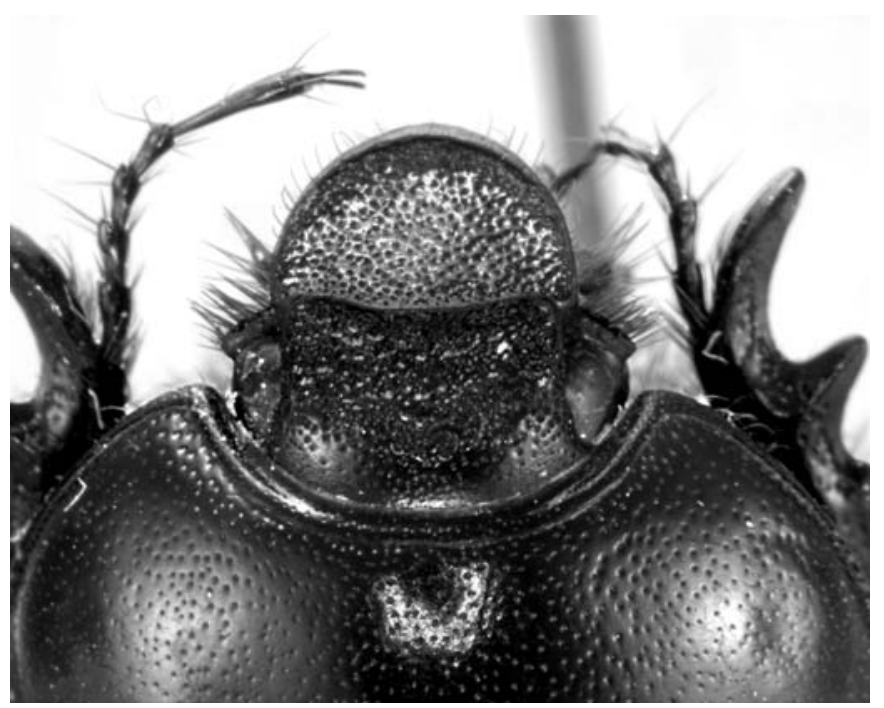

Fig. 2. Head (dorsal view) of Collagenus dasysternus.

clypeus. Mentum enlarged and strongly protuberant ventrally. Interocular width equals 5.0 transverse eye diameters. Anterior edge of eye canthus with dense, long, reddish brown setae. Antenna with 10 segments, club subequal in length to segments 2-7. Maxillary palpus with last segment longitudinally depressed and roughened on lateral edge, length 3 times longer than preceding (third) segment, third segment half as long as second segment. Pronotum: Surface entirely punctate; punctures moderate in density, size small (becoming slightly larger in anterior and

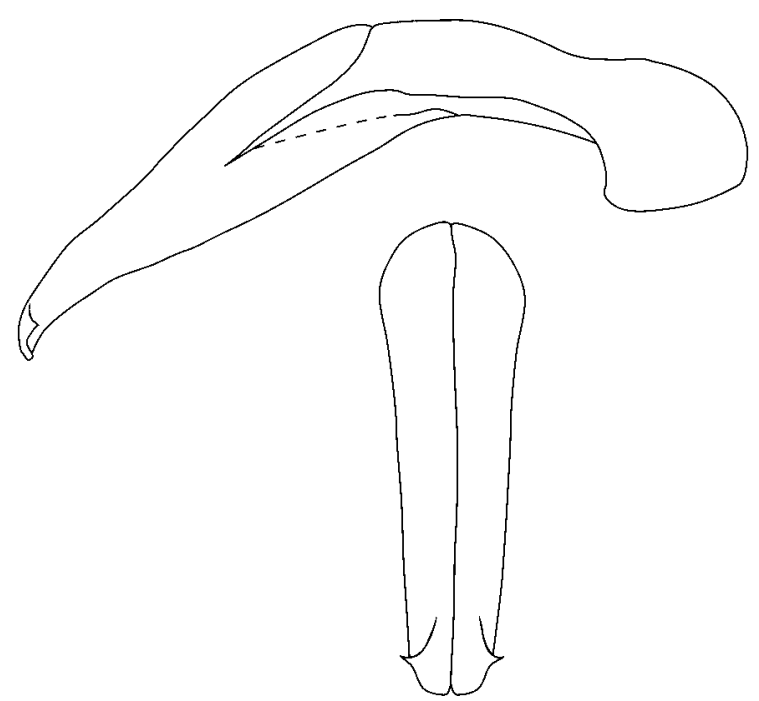

Figs. 3-4. Parameres of Collagenus dasysternus. 
posterior angles). All margins with strong bead. Sides evenly arcuate. Elytra: Surface between suture and humerus with 1 furrowed sutural stria and 2 pair of furrowed discal striae. Intervals slightly convex, those between striae 1-2 and 4-5 with irregular row of large punctures. Sides laterad of humerus with 4 distinct rows and 2 indistinct rows of punctures. Propygidium: Surface finely alutaceous with moderately dense, small punctures. Pygidium: Surface entirely punctate; punctures moderate in density and size, becoming slightly smaller at apex. In lateral view, surface strongly, evenly convex. Legs: Trochanter and femora with dense, long, yellowish brown setae. Tibiae with moderately dense, long, stout, yellowish brown setae, those on anterior femora mostly on venter. Foretibia tridentate, teeth becoming progressively larger from base to apex; apical tooth slightly removed from others, long, curved; apex of foretibia obliquely truncate. Meso- and metatibiae each with strong, obliquely transverse carina at about middle on lateral edge; apices expanded, each with fringe of long, stout bristles. Tarsi slender, subequal in length to their respective tibiae, each tarsomere at apex with 5-10 long, stout, reddish brown setae. Claws slender, equal in size. Venter: Thoracic sternites clothed with dense, long, yellowish brown setae. Prosternal process a very small, rounded protuberance. Abdominal sternites shining, glabrous except for about 20 small setae in a transverse row on penultimate segment. Last sternite with apex weakly bisinuate. Parameres: Figs. 3-4.

Etymology. From the Greek roots dasy, meaning shaggy or hairy, and sternon, meaning chest or sternum. So named in reference to the densely setose thoracic sternites, hence dasysternus.

Distribution. Known only from a single specimen collected in a flight intercept trap just north of Corocito, which is south of Ciudad Piar on the west side of Embalse de Guri in Bolivar state, Venezuela. Nothing is known of its biology.

\section{Revised Key to the Genera of New World Pentodontini}

1. Antenna with 9 segments …… $\quad$.

$1^{\prime}$. Antenna with 10 segments ................................................... 3

2(1). Head in both sexes with a short horn. Apical region of pronotum declivous. Argentina ….................................... Eremobothynus Ohaus 1910

2'. Head lacking horns, instead with a transverse carina. Apical region of pronotum not declivous. SW United States …...... Aphonides Rivers 1889

$3\left(1^{\prime}\right)$. Small species, generally less than $15 \mathrm{~mm}$ in length. Head lacking carina, tubercles, or horn (rarely with a trace of tubercles). Pronotum lacking tubercles or fovea. Posterior tibia strongly broadened towards apex ….... 4

$3^{\prime}$. $\quad$ Larger species, generally greater than $15 \mathrm{~mm}$ in length. Head with transverse carina (on subapex of clypeus or frontoclypeal suture), tubercles, or horn. Pronotum usually with tubercles (rarely obsolete in Aphonus, Indieraligus, Collagenus, some Tomarus, occasionally Philoscaptus) and usually with a fovea or sulcus behind tubercles. Posterior tibia not strongly broadened

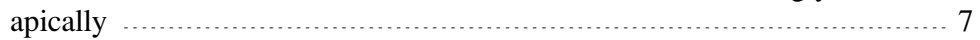

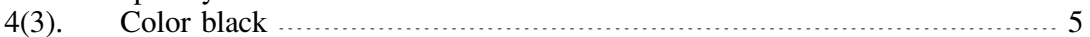

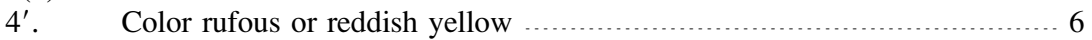

5(4). Pronotum completely and distinctly punctate. Propygidium lacks stridulatory striae. Southern United States through South America

Euetheola Bates 1888

5'. Pronotum virtually impunctate. Propygidium with stridulatory striae. African genus with one species introduced into southern Brazil

Heteronychus Burmeister 1847

6(4'). Posterior femur greatly thickened, apex of posterior tibia greatly expanded.

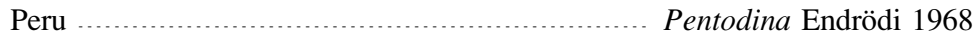

6'. Posterior femur normal, apex of posterior tibia not greatly expanded. Honduras to Brazil and Peru ................ Parapucaya (in part) Prell 1934 
$7\left(3^{\prime}\right)$. Size large $(30-35 \mathrm{~mm})$. Color rufous. Mandibles without teeth on external margin. Male with central horn on head, pronotum with a strong bifurcate tubercle or horn. Anterior tibia with a small, basal, fourth tooth. Posterior leg with basal tarsomere very wide. Propygidium without stridulatory striae. Argentina, Brazil, Colombia ....................... Thronistes Burmeister 1847

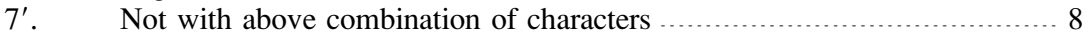

$8\left(7^{\prime}\right)$. Clypeal apex acute, unidentate …........................................... 9

8'. Clypeal apex bidentate, truncate, or rounded …........................ 10

9(8). Mandibles large, tridentate. Southern United States, northern Mexico Oxygrylius Casey 1915

9'. Mandibles smaller, nearly hidden by clypeus, lacking lateral teeth. South America ............................................ Oxyligyrus Arrow 1908

$10\left(8^{\prime}\right)$. High, transverse carina present immediately behind apex of clypeus ...... 11

10'. Transverse carina absent immediately behind apex of clypeus …........ 12

11(10). Transverse carina (usually tridentate) just behind apex of clypeus. Pronotum without tubercles. Size generally less than $17 \mathrm{~mm}$. United States west of the Rocky Mountains ................................... Aphonus LeConte 1856

11'. Transverse carina just behind apex of clypeus entire or bidentate. Pronotum tuberculate or not. Size generally greater than $17 \mathrm{~mm}$. Central and SW United States, Mexico, Guatemala, El Salvador, Nicaragua, Honduras

Orizabus Fairmaire 1878

$12\left(10^{\prime}\right)$. Mandibles only slightly visible from above or hidden under clypeus; outer edge arcuate, not toothed or convexly rounded …....................... 13

12'. Mandibles distinctly visible from above; outer edge toothed or convexly rounded or lobed ....................................................... 17

13(12). Clypeus strongly narrowed toward apex, apex narrowly bidentate. Color castaneous to black. Canada to Chile ...... Tomarus (in part) Erichson 1847

13'. Clypeus not strongly narrowed toward apex, apex broadly truncate. Color fulvous to rufocastaneous .............................................. 14

$14\left(13^{\prime}\right)$. Frontoclypeal suture present, deeply impressed, strongly arcuate either side of middle. Head lacking horns or tubercles. Length $14 \mathrm{~mm}$ or less. Honduras to Brazil and Peru Parapucaya (in part) Prell 1934

14'. Frontoclypeal suture absent. Head with horns, tubercles, or low boss. Length

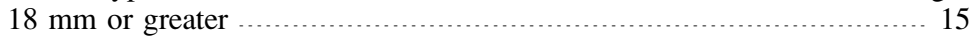

15(14'). Small horn (males) or tubercle (females) present next to each eye. Apex of pronotum declivous with subapex weakly to strongly bituberculate. Panama, Colombia, Ecuador ....................................... Pucaya Ohaus 1910

15'. Paired horns or tubercles absent. Center of head with, at most, a low boss. Apex of pronotum evenly convex ….................................... 16

$16\left(15^{\prime}\right)$. Clypeus with apex strongly emarginate, reflexed, apical rim thin. Center of head slightly tumid. Prosternal process long, columnar. SW United States, N. Mexico ............................................. Coscinocephalus Prell 1936

16'. Clypeus with apex broadly parabolic, apical rim strongly thickened (Fig. 2). Center of head with strong, elevated carina, carina complete from side to side. Prosternal process small, rounded. Venezuela

Collagenus Ratcliffe and Hardy, new genus

17(12'). Mandibles entire or lobed on lateral edge …............................. 18

17'. Mandibles distinctly tridentate (1 apical tooth, 2 lateral teeth) ............. 23

18(17). Apex of clypeus narrowly bidentate. Ecuador (Galapagos Islands) Neobothynus Prell 1936

18'. Apex of clypeus truncate, acute, or narrowly rounded ................... 19 $19\left(18^{\prime}\right)$. Clypeus abruptly constricted at apex; tip elongate, narrowly truncate or 
rounded. Males with head horn, pronotum with bifurcate horn; females lacking horns. Color piceous (females) to grey-tomentose (males), opaque. Brazil, Argentina

Diloboderus Reiche 1859

19'. Clypeus regularly acuminate, subtriangular. Horns absent. Color castaneous,

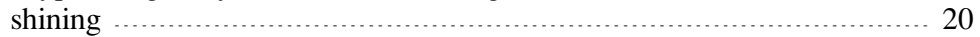

$20\left(19^{\prime}\right)$. Pronotum lacking distinct apical fovea, sulcus, or tubercle or fovea either side of middle; marginal bead absent on base. Scutellum impunctate. Base of pygidium, lateral edge of abdominal sternites and meso- and metatibiae with extremely long, dense setae. Puerto Rico ..... Indieraligus Dechambre 1979

20'. Pronotum with distinct apical fovea, sulcus, or tubercle or fovea either side of middle; marginal bead present on base. Scutellum with punctures. Setae present on meso- and metatibiae, pygidium, or sternites but extremely long

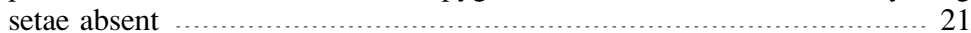

$21\left(20^{\prime}\right)$. Clypeus strongly convex on dorsal surface. Frontoclypeal suture strongly elevated into a transverse, weakly bituberculate ridge. Pronotum with a shallow, ovoid concavity in median half behind subapical tubercle (male) or with subapical rounded swelling (female). Elytron with sutural stria and 3 feebly indicated discal striae. Mexico ….......... Gillaspytes Howden 1980

21'. Clypeus not strongly convex on dorsal surface, either weakly convex in basal half only or weakly concave. Frontoclypeal suture with a transverse tubercle only. Pronotum lacking a shallow, ovoid concavity in median half behind apical margin, instead a median longitudinal sulcus or a shallow fovea either side of middle. Elytron with sutural stria and 4-5 punctate-striate rows on

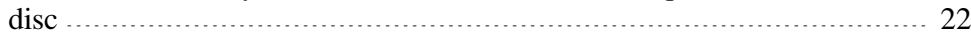

$22\left(21^{\prime}\right)$. Apex of clypeus narrowly truncate. Tubercle on head entire. Pronotum with shallow fovea either side of disc; subapical sulcus and apical tubercles absent. Metasternum setigerously punctate in anterior half only. Paraguay Heikeianus Endrödi 1978

22'. Apex of clypeus narrowly rounded. Tubercle on head feebly emarginate. Pronotum without fovea either side of middle; both sexes with a weak, subapical, longitudinal sulcus (weaker in females), and males with an apical, emarginate tubercle. Metasternum completely, setigerously punctate. Panama, Costa Rica Barutus Ratcliffe 1981

23(17'). Propygidium with stridulatory striae or granules ........................ 24

$23^{\prime}$. Propygidium lacking stridulatory striae or granules …................ 26

24(23). Apical segment of maxillary palpus expanded, triangular. South America Hylobothynus Ohaus 1910

24'. Apical segment of maxillary palpus normal, cylindrical …................ 25

25(24'). Foretibia tridentate. Mexico through South America

Bothynus Hope 1837

25'. Foretibia bidentate. Southern Brazil ............. Parabothynus Endrödi 1968

$26\left(23^{\prime}\right)$. Elytron with sparse, minute punctures, appearing smooth. Clypeus on sides constricted at base. Southern Brazil ....................... Aceratus Prell 1936

26'. Elytron distinctly punctate or punctate-striate. Clypeus not constricted at

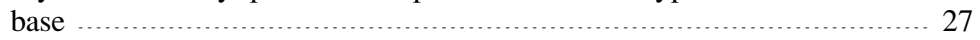

$27\left(26^{\prime}\right)$. Body form suboval, stout, strongly convex on dorsum. Surface coarsely punctate-striate. Frontoclypeal carina short, less than $1 / 3$ width of base of clypeus. Pronotum evenly convex or with a trace of an apical tubercle. Argentina, Uruguay, S. Brazil …................. Philoscaptus Bréthes 1919

$27^{\prime}$. Body form more elongate, less stout, not strongly convex on dorsum. Surface variably punctate. Frontoclypeal carina long, interrupted at middle or not or 
replaced by 2 distinct tubercles. Pronotum with or without apical tubercle and subapical fovea. Canada to Chile Tomarus (in part) Erichson 1847

\section{Acknowledgments}

We thank Henry Howden for making the specimen available from his collection. We are grateful to Angie Fox (Scientific Illustrator, University of Nebraska State Museum) for the habitus drawing and to François Génier (Canadian Museum of Nature) for the photograph. Mary Liz Jameson and Matt Paulsen provided valuable commentary for improving the manuscript as did two anonymous reviewers. This project was supported by an NSF/PEET grant (DEB 0118669) to M. L. Jameson and B. C. Ratcliffe and an NSF/BS\&I grant (DEB 9870202) to B. C. Ratcliffe and R. D. Cave.

\section{Literature Cited}

Endrödi, S. 1969. Monographie der Dynastinae 4. Tribus: Pentodontini (Coleoptera, Lamellicornia). Entomologische Abhandlungen 87:1-145.

Endrödi, S. 1985. The Dynastinae of the World. W. Junk Publishers, Dordrecht. 800 pp.

Machatschke, J. W. 1972. Scarabaeoidea: Melolonthidae Rutelinae. Coleopterorum Catalogus Supplementa, Pars 66, Fascicle 1(second edition):1-361.

Morón, M. A., and B. C. Ratcliffe. 1996. New tribal placement of the genus Coscinocephalus Prell, 1936, with description of the larva, pupa, and adult of a new species from Mexico (Coleoptera: Scarabaeoidea: Dynastinae). Journal of the New York Entomological Society 104:48-61.

Ratcliffe, B. C. 1981. Barutus hartmanni, a new genus and species from Panama with a key to the New World genera of Pentodontini (Coleoptera: Scarabaeidae: Dynastinae). Coleopterists Bulletin 35:463-472.

Ratcliffe, B. C. 2002. Chapter 34-V. Dynastinae MacLeay 1819 [pp. 64-67]. In: American beetles, Volume 2 (R. H. Arnett, M. Thomas, P. E. Skelley, and J. H. Frank, editors.). CRC Press, Boca Raton, FL. 861 pp.

Wheeler, Q. D., and N. I. Platnick. 2000. The phylogenetic species concept (sensu Wheeler and Platnick) [pp.-69]. In: Species concepts and phylogenetic Theory. A Debate (Q. D. Wheeler, and R. Meier, editors). Columbia University Press, NY. 230 pp.

(Received 7 October 2004; accepted 6 December 2004. Full page charges borne by the authors. Publication date 19 April 2005.) 